$\begin{array}{ccc}\text { Tersedia online di: http://ejournal-balitbang.kkp.go.id/index.php/jppi } & \text { JURNAL } \\ \text { e-mail:jppi.puslitbangkan@gmail.com } & \text { PENELITIAN } \\ \text { PERIKANAN } & \text { INDONESIA } \\ \text { JURNALPENELITIANPERIKANANINDONESIA } & \text { Volume 23 Nomor 4 Desember 2017 } \\ \text { e-ISSN: 2502-6542 } & \\ \text { Nomor Akreditasi: 653/AU3/P2MI-LIPI/07/2015 }\end{array}$

\title{
PARAMETER POPULASI, ASPEK BIOLOGI DAN PENANGKAPAN TONGKOL KOMO (Euthynnus affinis Cantor, 1849) DI SELAT MALAKA
}

\section{POPULATION PARAMETER, BIOLOGICAL ASPECT AND FISHING OF MACKEREL TUNA (Euthynnus affinis Cantor, 1849) IN MALACCA STRAIT}

\author{
Karsono Wagiyo*1, Andina Ramadhani Putri Pane' dan Umi Chodrijah' \\ 'Balai Riset Perikanan Laut, Kompl. Raiser Jl. Raya Bogor KM. 47 Nanggewer Mekar, Cibinong, Bogor \\ Teregistrasi I tanggal: 25 Oktober 2017; Diterima setelah perbaikan tanggal: 21 Desember 2017; \\ Disetujui terbit tanggal: 08 Januari 2018
}

\begin{abstract}
ABSTRAK
Tongkol komo (Euthynnus affinis) merupakan komoditas perikanan ekonomis penting. Di Selat Malaka sumber daya tongkol komo merupakan stok bersama antara Indonesia dan Malaysia yang telah dimanfaatkan secara intensif dengan berbagai alat tangkap. Dalam rangka pengelolaan sumber daya ikan tongkol komo di Selat Malaka supaya tetap lestari, penelitian ini dilakukan dengan tujuan memperoleh informasi mengenai parameter populasi, aspek biologi dan aspek penangkapan. Penelitian dilakukan secara observasi, enumerasi dan wawancara. Hasil penelitian menunjukkan nilai berbagai parameter populasi; panjang maksimum tercapai $(\mathrm{L} \infty)=64,25 \mathrm{cmFL}$, laju pertumbuhan $(K)=0,96 /$ tahun, laju kematian alami $(M)=1,38$ /tahun, laju kematian karena penangkapan $(F)=1,41$ tahun, panjang pertama tertangkap $(\mathrm{Lc})=34,5 \mathrm{cmFL}$ dan panjang pertama matang gonad $(\mathrm{Lm})=41,02 \mathrm{cmFL}$ dan laju pengusahaan $(E)=0,50$. Dari aspek biologi diperoleh; nisbah kelamin betina : jantan $=1: 1,15$, puncak gonad matang dan indek kematangan gonad terjadi pada Maret dan November, mangsa dominan ikan teri (Stolephorus sp.). Alat tangkap utama untuk penangkapan tongkol komo berupa pukat langgai (purse seine). Nilai CPUE tertinggi diperoleh pada Juli dengan musim penangkapan terjadi pada periode April-Juli. Kontribusi tangkapan ikan tongkol komo sebesar 17,42-27,20 \% dari total tangkapan ikan. Jenis ikan tangkapan utama yang berinteraksi dengan tongkol komo adalah kembung (Rastrelliger sp.) dan layang (Decapterus sp). Parameter yang bersifat negatif terhadap kelestarian populasi ikan tongkol komo, seperti ukuran ikan dan hasil tangkapan per unit usaha nilainya kecil. Parameter yang bersifat positif antara lain; rasio antara nilai kematian alami dengan nilai laju pertumbuhan masih dalam kisaran normal dan nilai tingkat pengusahaan masih dalam kisaran optimum. Penangkapan ikan tongkol komo di Selat Malaka masih dalam keadaan normal, tetapi perlu pengawasan terhadap mata jaring dan alat tangkap yang digunakan serta aktifitas penangkapan pada musim pemijahan. Adanya interaksi dengan jenis ikan pelagis kecil dan dominasi ikan teri dalam isi lambung, sehingga dalam pengelolaan ikan tongkol komo harus dilakukan bersama dengan kedua komoditi.
\end{abstract}

Kata Kunci : Tongkol komo; parameter populasi; aspek biologi; penangkapan; Selat Malaka

\section{ABSTRACT}

Mackerel tuna (Euthynnus affinis) is an important economic fishery commodity. In the Malacca Strait, mackerel tuna resource is a share stock between Indonesia and Malaysia that has been used intensively with various fishing gear. In order to manage the fish resources of mackerel tuna in the Malacca Strait to be sustainable, this research is conducted with the aim of obtaining information on parameteer population, biology aspects and fishing aspects. The research was conducted by observation, enumeration and interview. The results showed the values of various population parameters: length infinity $\left(L_{\infty}\right)=64.25 \mathrm{cmFL}$, growth rate $(K)=0.96 /$ year, natural mortality rate $(M)=1.38$ /year, capture mortality rate $(F)=1.41$ /year, length of first captured $(L C)=$ 
$34.5 \mathrm{cmFL}$ and length of first maturity $(L \mathrm{~m})=41.02 \mathrm{cmFL}$ and exploitation rate $(E)=0,50$. Biological aspect was obtained; sex ratio female : male $=1: 1.15$, peak of mature gonad and index gonad maturity occurred in March and November, main prey are anchovy (Stolephorus sp.). The main fishing gear for catching mackerel tuna is purse seine. The highest CPUE value was obtained in July with the fishing season occurring in the April-July period. The contribution of catch mackerel tuna are $17.42-27.20 \%$ of the total catch of fish. The main species of fish that interact with mackerel tuna are mackerel (Rastrelliger sp.) and sardine (Decapterus sp). Negative parameters to sustainability of mackerel tuna population such as fish size and catch per unit effort are small. Positive parameters are the ratio between the value of natural mortality and the rate of growth is still within the normal range and the level of exploitations rate is still within the optimum range. The fishing of mackerel tuna in the Malacca Strait is still in normal condition, but it is necessary to monitor of the nets mesh size and fishing gear used and fishing activity on spawning season. The existence of interaction with small pelagic fish species and the dominance of anchovy in the contents of the stomach, so that in the management of mackerel tuna fish should be done together with the two commodities.

\section{Keywords: Mackerel tuna; population parameter; biological aspect; fishing; Malacca strait \\ PENDAHULUAN}

Tongkol komo (Euthynnus affinis) merupakan komoditas ikan pelagis besar dari famili Scombridae yang meliputi $10 \%$ perdagangan seafood dunia (Ahmed et al., 2015). Tongkol komo bersifat oseanodromous menyebar pada area pantai dan sekitar pulau di daerah tropis dan subtropis (Williams, 1963; Chiou \& Lee, 2004; Rohit et al., 2012). Tongkol komo bergerombol dengan ikan seukuran dari anggota Scombridae dan tertangkap dengan berbagai alat tangkap (Ahmed et al., 2015). Tongkol merupakan predator utama dari berbagai jenis mangsa seperti ikan kecil, cumi-cumi dan krustasea (Carpenter \& Niem, 2001).

Di Indonesia ikan tongkol komo merupakan komoditas ekonomis penting yang strategis karena merupakan sumber mata pencaharian nelayan dan sumber devisa negara. Produksi tongkol komo pada 2010 sebesar 390.595 ton, terus mengalami peningkatan rerata per tahun $7,27 \%$, menjadi 520.460 ton pada 2015 (KKP, 2015). Sebaran tongkol komo di Indonesia meliputi seluruh laut yang bersifat neritik. Salah satu wilayah perairan Indonesia yang merupakan daerah sebaran dan habitat tongkol komo adalah Selat Malaka.

Tongkol komo di Selat Malaka merupakan stok bersama. Pemanfaatan tongkol komo di Selat Malaka terutama dilakukan oleh nelayan Indonesia dan Malaysia. Tujuh puluh persen nelayan Semenanjung Malaya melakukan aktifitasnya di Selat Malaka (Jagerrooss, 2016). Alat yang digunakan oleh kedua nelayan secara teknis hampir sama yaitu: pukat langgai/pukat cincin (purse seine), jaring insang (gillnet) dan pancing tonda (trolling). Pendaratan tongkol komo asal Selat Malaka di Malaysia dimulai pada 2003 dengan jumlah hasil tangkapan 819 ton, terus naik mencapai puncaknya pada 2012 sebesar 10.478 ton (Samsudin et al., 2014). Pemanfaatan sumber daya perikanan Selat Malaka diperkirakan mencapai nilai US\$358 juta bagi Malaysia dan US\$168 juta bagi Indonesia (Jagerroos, 2016).

Mengingat peran strategis tongkol komo di Selat Malaka dan kurangnya data dan informasi, maka penelitian sangat diperlukan untuk mengelola sumber daya tongkol komo secara lestari. Dalam mendukung pengelolaan perikanan dilakukan penelitian yang bertujuan untuk memperoleh data parameter populasi, aspek biologi dan penangkapannya.

\section{BAHAN DAN METODE Waktu dan Lokasi Penelitian}

Penelitian dilakukan selama periode Januari-November 2014. Lokasi pendataan ikan hasil tangkapan nelayan adalah di Langsa- Aceh Timur dan BelawanSumatera Utara (Gambar 1). 


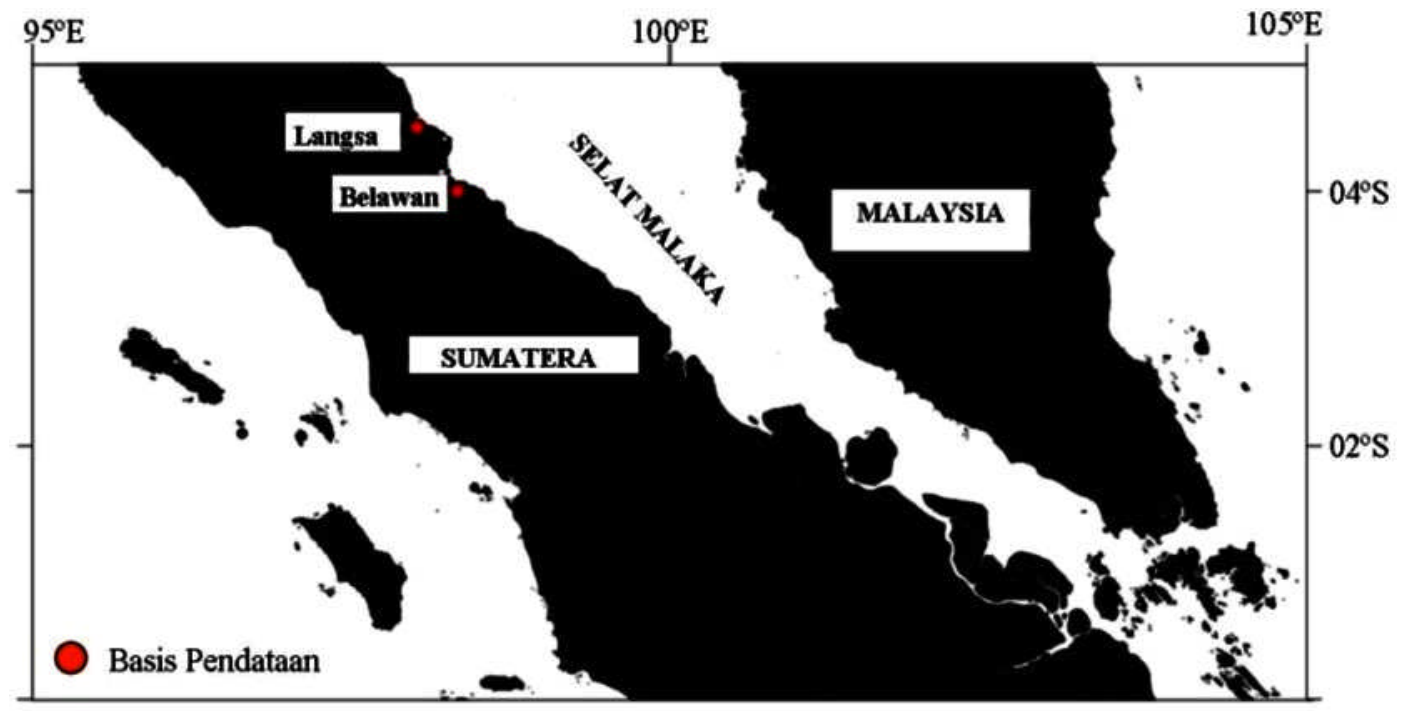

Gambar 1. Peta menunjukan lokasi pendaratan dan daerah penangkapan ikan tongkol komo.

Figure 1. Map showing landing site and fishing ground of mackerel tuna.

\section{Sampling dan Pengumpulan Data}

Sampling untuk mendapatkan data parameter populasi secara porposional dilakukan dengan bantuan enumerator yang mengukur panjang cagak ikan yang didaratkan harian selama periode penelitian. Sedangkan sampling data biologi dilakukan langsung pada saat observasi lapangan. Pengumpulan data aspek penangkapan dilakukan dengan cara observasi, enumerasi dan wawancara.

\section{Analisa Sampel}

Pengamatan tingkat kematangan gonad mengikuti panduan dari Matsumoto \& Miyabe (2002) yaitu: (i) tingkat kematangan gonad I (immature), gonad memanjang dan ramping, ovari jernih berwarna abuabu hingga kemerah-merahan; (ii) tingkat kematangan gonad II (Early maturing), gonad membesar telur seperti serbuk putih, ovari berwarna kemerah-merahan dengan pembuluh kapiler mengisi sekitar setengah rongga perut bagian bawah; (iii) tingkat kematangan gonad III (Late maturing), gonad terlihat membengkak, telur dapat dilihat dengan mata biasa, ovari berwarna oranye kemerah-merahan mengisi $2 / 3$ rongga perut bagian bawah; (iv) tingkat kematangan gonad IV (Ripe) ovari sangat membesar, telur jernih dan masak, mudah keluar dari lumen ovari kalau perut ditekan, gonad mengisi penuh rongga perut bagian bawah; dan (v) tingkat kematangan gonad V (Spent), ovari sangat besar dan lunak, telur matang yang tertinggal dalam keadaan terserap, jernih dan akan keluar dengan sedikit tekanan pada perut.

\section{Analisa Data}

Indek kematangan gonad (gonado somatic index) dihitung dengan menggunakan persamaan sebagai berikut (Zudaire et al., 2010):

$\mathrm{GSI}=(\mathrm{Wg} / \mathrm{BW}) \times 100 \%$

dimana;

$\mathrm{Wg}=$ Berat gonad segar

$\mathrm{BW}=$ Berat individu ikan

Ukuran pertama kali matang gonad (Length at first mature) diduga dengan cara Spearman-Karber menurut acuan Udupa (1956) sebagai berikut:

$m=X k+(X / 2)-\left(X \sum p i\right)$

dimana;

$m=$ Log panjang ikan pada kematangan gonad pertama

$\mathrm{Xk}=$ Log nilai tengah kelas panjang semua ikan 100 $\%$ matang gonad

$\mathrm{pi}=$ Proposi ikan matang pada kelas $\mathrm{i}$, bila $\mathrm{pi}=\mathrm{ri} /$ ni dan $n i=n i+1$

Penentuan perbandingan kelamin (sex ratio) mengikuti persamaan Chiang et al. (2011) sebagai berikut :

Seks rasio $=\frac{\text { Jumlah Betina }}{\text { Jumlah Betina }+ \text { Jumlah Jantan }} X 100$ 
Isi lambung dominan, dihitung berdasarkan persentase berat masing-masing jenis organisme, sebagai berikut;

Persentase jenis dominan $=\frac{\text { Jumlah berat satu jenis organisme }}{\text { Jumlah berat total seluruh jenis organisme }} \times 100 \cdots$

Indeks kelimpahan di indikasikan besaran Catch per Unit effort (CPUE) dihitung sebagai berikut:

CPUE $=\frac{C w}{T}$

dimana;

CPUE $=$ Catch per Unit Effort

$\mathrm{Cw}=$ Berat hasil tangkapan

$\mathrm{T} \quad=$ Trip penangkapan

Parameter pertumbuhan ( $\mathrm{K}$ dan $\mathrm{L} \infty)$ ditentukan melalui persamaan Von Bertalanffy (Sparre \& Venema, 1992) sebagai berikut:

$L t=L \infty\left(1-e^{-K(t-t 0)}\right)$

di mana;

$\mathrm{Lt}=$ panjang ikan saat umur ke-t $(\mathrm{cm})$

$\mathrm{L}_{\infty}=$ panjang asimtotik ikan $(\mathrm{cm})$

$\mathrm{K}=$ laju pertumbuhan ikan

Laju kematian total $(Z)$ dengan rumus Pauly (1980):

$\operatorname{Ln~N/t}=a-Z t$

dimana;

$\mathrm{N}=$ banyaknya ikan pada waktu $\mathrm{t}$

$\mathrm{t}=$ waktu yang diperlukan untuk tumbuh suatu kelas panjang

$\mathrm{a}=$ hasil tangkapan yang dikonversikan terhadap panjang

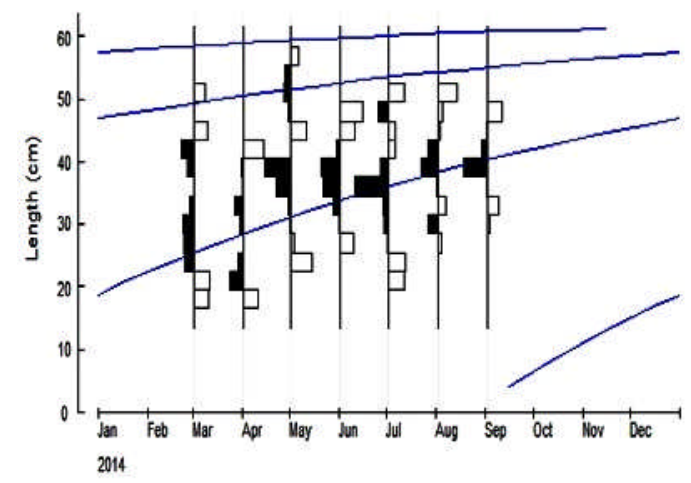

a
Laju kematian alami (M) dihitung dengan rumus Pauly (1980) sebagai berikut:

$\log M=-0,0066-0,654 \log K+0,4534 \log T$.

dimana;

$M=$ laju kematian alami

$\mathrm{L}=$ panjang maksimum $(\mathrm{cm})$

$\mathrm{K}=$ laju Pertumbuhan(cm/tahun)

$\mathrm{T}=\operatorname{suhu}\left({ }^{\circ} \mathrm{C}\right)$

Laju kematian karena penangkapan $(F)$ didapatkan dari pengurangan laju kematian total dengan laju kematian alami. Laju pengusahaan didapatkan dari perbandingan nilai $F$ dengan nilai $Z$.

\section{HASIL DAN BAHASAN}

Hasil

\section{Pola Pertumbuhan}

Plot hasil pengukuran bulanan menunjukkan sebaran frekuensi panjang cagak ikan tongkol komo bernilai modus yang berbeda sesuai dengan bulan pengamatan (Gambar 2a). Pelacakan garis modus pertumbuhan dengan model Von Bertalanfly diperoleh laju pertumbuhan $(K)=0,96$ /tahun dan panjang asimtotik (L") sebesar $64,25 \mathrm{cmFL}$.

\section{Laju Kematian dan Laju Pengusahaan}

Hasil linierisasi pameter pertumbuhan menunjukkan, ikan tongkol komo di perairan Selat Malaka mempunyai nilai kematian total $(Z)=2,79 /$ tahun (Gambar $2 b$ ). Kalkulasi nilai kematian alami (M) didapatkan 1,38/ tahun. Pengurangan nilai $Z$ dengan nilai kematian alami didapatkan kematian karena penangkapan $(F)=1,41 /$ tahun. Laju pengusahaan (E) didapatkan dari pembagian nilai $F$ dengan nilai $Z$ sebesar $0,50 /$ tahun.

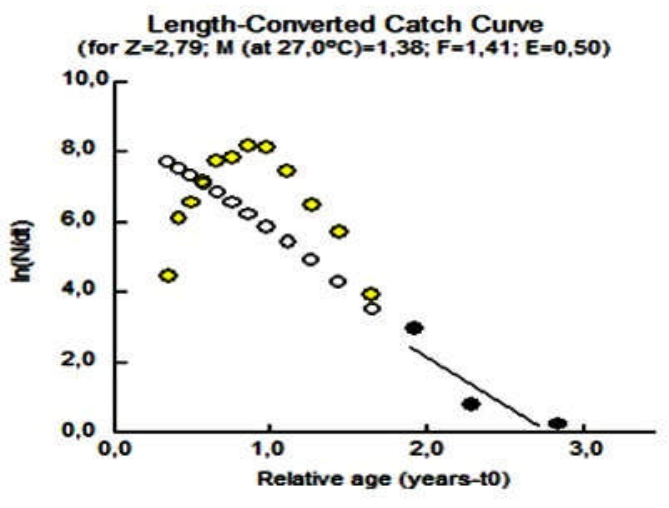

b

Gambar 2. a) Garis pertumbuhan dan b) Laju kematian dan pengusahaan ikan tongkol komo di Selat Malaka.

Figure 2. a) Growth line and b) mortality \& exploitation rate of mackerel tuna in Mallaca Strait. 
Panjang Pertama Tertangkap dan Matang Gonad

Pengamatan terhadap 1.900 ekor tongkol komo dari perairan Selat Malaka didapatkan ukuran ikan

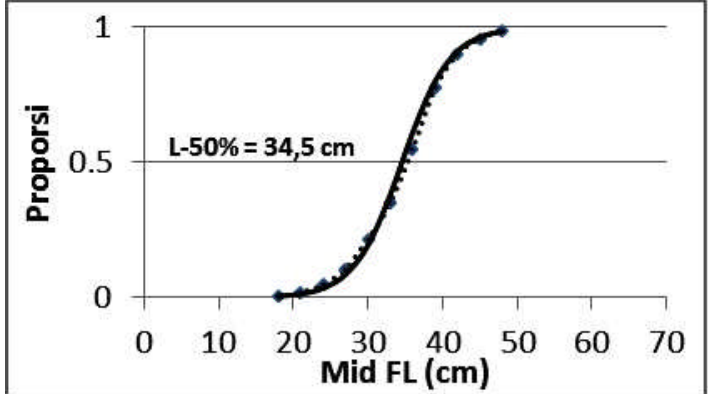

pertama tertangkap (LC) dengan pukat langgai pada panjang 34,5 cmFL (Gambar 3a). Panjang pertama matang gonad $(\mathrm{Lm})$ tongkol komo sebesar 41,02 cmFL.

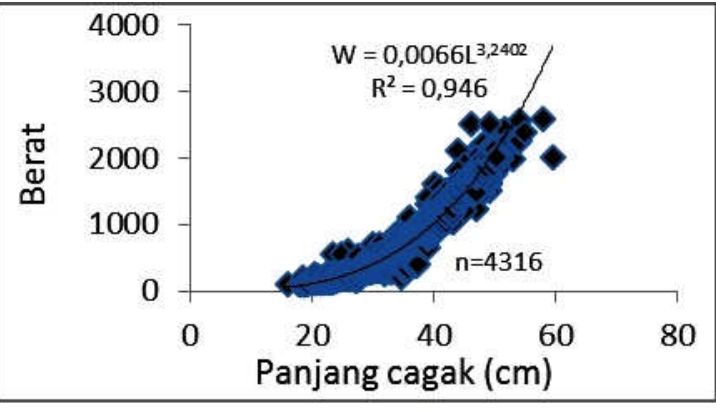

b

Gambar 3. a) Ukuran pertama tertangkap dan b) hubungan panjang-berat ikan tongkol komo dari Selat Malaka Figure 3. a) Size of first catch and b) Length-weight relation of Mackerel tuna from Mallaca strait.

\section{Hubungan Panjang-Berat}

Hasil pengukuran panjang cagak ikan tongkol komo didapatkan pada kisaran 16-60 cmFL dengan rerata $38 \mathrm{cmFL}$, berat didapatkan kisaran 93$2.577 \mathrm{gr}$, dengan rerata $957 \mathrm{gr}$. Hubungan panjang berat mempunyai nilai $R^{2}=0,946$ dan nilai $b=3,2402$ (Gambar 3b)

\section{Tingkat Kematangan Gonad}

Keadaan kematangan gonad tongkol komo di Selat Malaka berbeda antar bulan, dengan puncak kematangan gonad terjadi pada Maret dan November (Gambar 4a). Pola perkembangan gonad dimulai pada Januari, sebagian besar dalam keadaan belum matang/immature (TKG I \& TKG II) sebanyak 90,48 $\%$. Pada Maret gonad matang meningkat menjadi $75 \%$ yang terdiri dari TKG V $25 \%$, TKG IV $25 \%$ dan TKG III $25 \%$. Pada bulan berikutnya sampai dengan Juli gonad matang menurun menjadi 50 $\%$. Pada Agustus meningkat lagi, sampai dengan November gonad matang mencapai 100 $\%$ dengan komposisi TKG III 14,29 \% dan TKG IV $85,71 \%$.

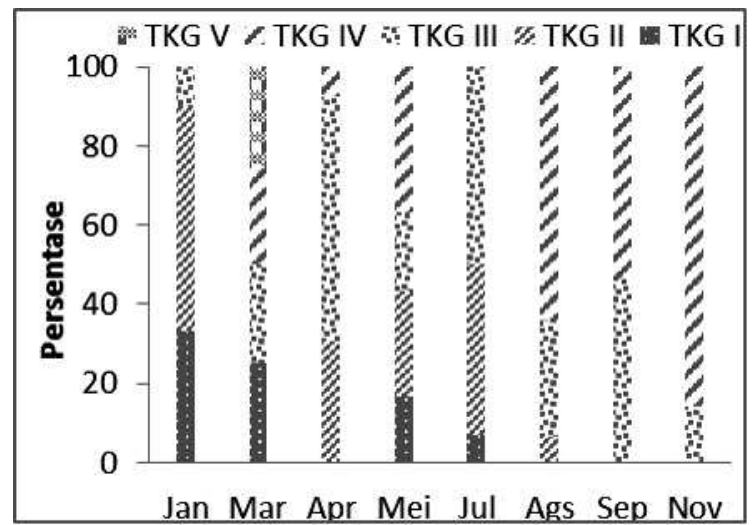

a

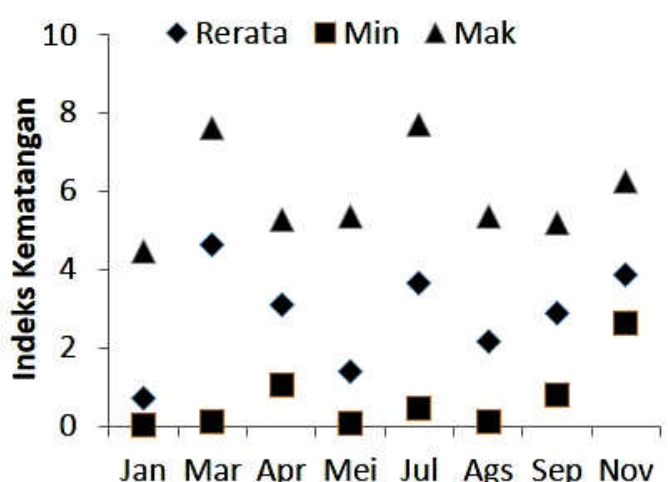

b

Gambar 4. Kematangan gonad (a) dan Indek kematangan gonad ikan tongkol komo (Euthynnus affinis) (b) di Selat Malaka.

Figure 4. Gonad maturity and (a) Gonad index of mackerel tuna (Eutyhynnus affinis) (b) based on month in Mallaca Strait.

\section{Indeks Kematangan Gonad}

Indeks kematangan gonad tongkol komo di perairan Selat Malaka berfluktuasi secara bulanan dengan nilai kisaran 0,02-7,72 (Gambar 4b). Nilai rerata indek kematangan gonad menunjukkan ada dua puncak, yang terjadi pada Maret dan November. Pola fluktuasi IKG dimulai dari Januari dengan nilai rerata terendah $(0,69)$, menuju Maret IKG naik menjadi 4,64, kemudian pada Mei menurun menjadi 1,41. Pada bulan Juli IKG naik kembali menjadi 3,66 diikuti dengan penurunan pada Agustus menjadi 2,51. Pada bulan 
berikutnya, September sampai dengan November indeks kematangan gonad meningkat menjadi 3,88.

\section{Nisbah Kelamin}

Nisbah kelamin ikan tongkol komo bervariasi antar bulan dengan total terdiri dari betina $46,58 \%$ dan jantan $53,42 \%$ (Gambar 5a). Kelamin betina dominan pada Maret, Juli dan November masing-masing mempunyai kontribusi $75 \%, 64,29 \%$ dan $57,14 \%$. Kelamin jantan dominan pada Mei dan Agustus masing-masing mempunyai konstribusi $58,62 \%$ dan $65,96 \%$. Nisbah kelamin seimbang terjadi pada Januari, April dan September.

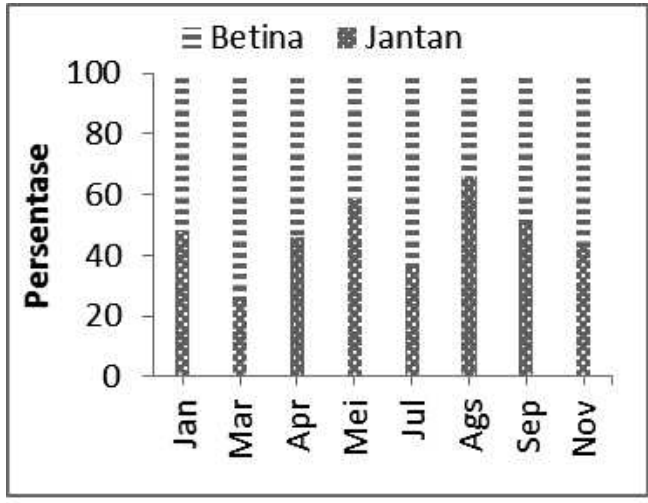

a

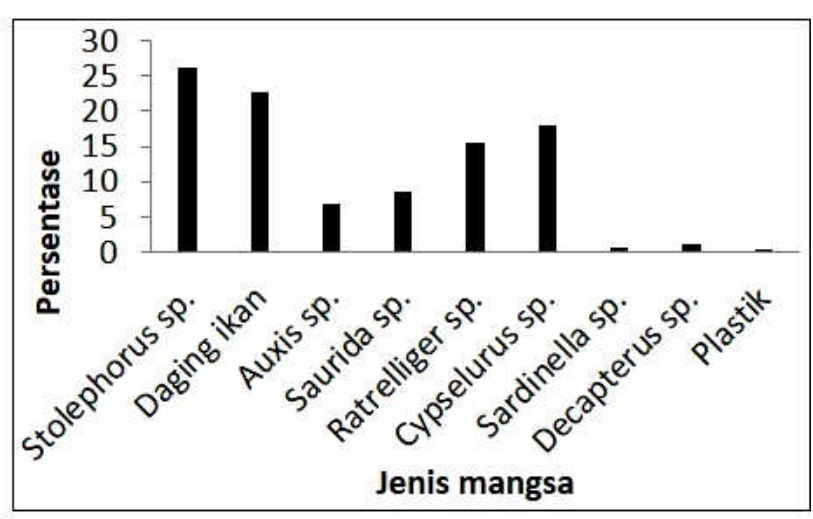

b

Gambar 5. a) Nisbah kelamin dan b) isi lambung ikan tongkol komo (Euthynnus affinis) di Selat Malaka. Figure 5. a) Sex ratio and b) Stomach contens of mackerel tuna (Eutyhynnus affinis) in Mallaca Strait.

\section{Isi Lambung}

Isi lambung ikan tongkol komo ada 9 komponen terdiri dari tujuh genus mangsa, potongan daging ikan dan material plastik (Gambar 5b). Jenis mangsa dominan berupa ikan teri (Stolephorus sp.), ikan terbang (Cypselurus sp.) dan ikan kembung (Rastrelliger sp.) masing-masing mempunyai kontribusi $26,27 \%, 17,93 \%$ dan $15,60 \%$.

\section{Alat Tangkap dan Operasi Penangkapan}

Penangkapan ikan tongkol komo di Selat Malaka, yang utama dilakukan dengan menggunakan pukat langgai/pukat cincin (purse seine). Ada dua tipe pukat langgai yang berukuran kecil $400 \mathrm{~m} \times 32 \mathrm{~m}$ dan besar $700 \mathrm{~m} \times 60 \mathrm{~m}$. Kedua tipe mempunyai mesh size yang sama 4 inchi.

Dalam pengoperasian pukat langgai digunakan alat bantu rumpon dan cahaya lampu, armada yang digunakan ada dua ukuran sesuai dengan ukuran jaring yang dioperasikan. Untuk pukat langgai kecil digunakan ukuran perahu $15 \mathrm{~m} \times 4 \mathrm{~m} \times 2 \mathrm{~m}$ dan untuk pukat berukuran besar digunakan kapal berukuran 27 $\mathrm{m} \times 7 \mathrm{~m} \times 3 \mathrm{~m}$. Tenaga penggerak kapal mesin Fuso D14. Pengoperasian pukat kecil dilakukan oleh 1518 anak buah kapal (ABK) dan yang besar oleh 18$20 \mathrm{ABK}$. Lama trip pukat kecil 4-5 hari dan pukat besar 6-7 hari. Kegiatan penangkapan pada siang/malam hari, dalam satu hari dilakukan 1-2 kali. Daerah penangkapan berbatasan dengan teritorial Malaysia pada kedalaman perairan $\pm 80 \mathrm{~m}$.

\section{Hasil Tangkapan per Upaya (CPUE) dan Musim Penangkapan}

CPUE ikan komo dengan pukat langgai didapatkan kisaran $165-1.100 \mathrm{~kg} /$ trip (Gambar 6a). CPUE rerata terendah $493 \mathrm{~kg} /$ trip didapatkan pada Maret dan tertinggi $795 \mathrm{~kg} /$ trip didapatkan pada Juli. Musim penangkapan dimulai April-sampai dengan akhir Juli terjadi puncak penangkapan (Gambar 6b). Musim penangkapan didahului dan diakhiri oleh musim paceklik.

\section{Interaksi dan Komposisi Jenis Tangkapan}

Penangkapan ikan tongkol komo menggunakan pukat langgai (pure seine) di Selat Malaka berinteraksi dengan 10 jenis ikan lainnya (Gambar 7). Konstribusi ikan tongkol komo bulanan terhadap hasil tangkapan pukat langgai rata-rata sebesar $22,81 \%$, terkecil 17,41 $\%$ terjadi pada Juni dan terbesar $27,20 \%$ terjadi pada Mei. Jenis ikan utama yang berinteraksi dengan ikan tongkol komo dalam penangkapan dengan pukat langgai adalah ikan kembung (Rastrelliger spp.) dan ikan layang (Decapterus spp.) masing-masing mempunyai kontribusi rerata bulanan adalah 25,34 $\%$ dan $23,44 \%$. 


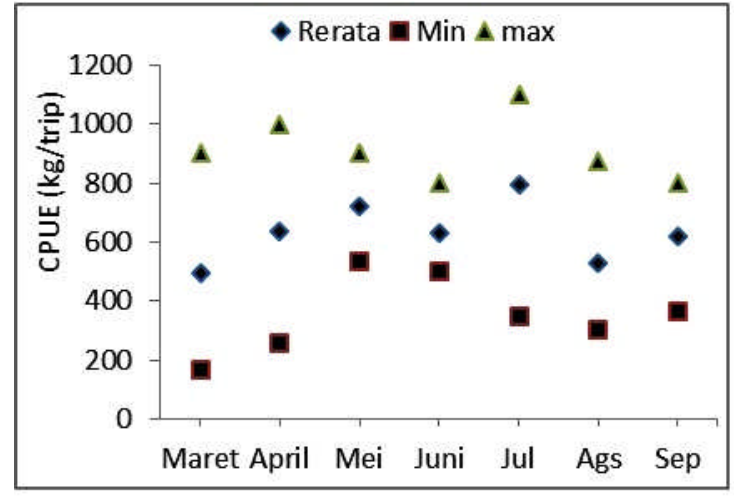

a

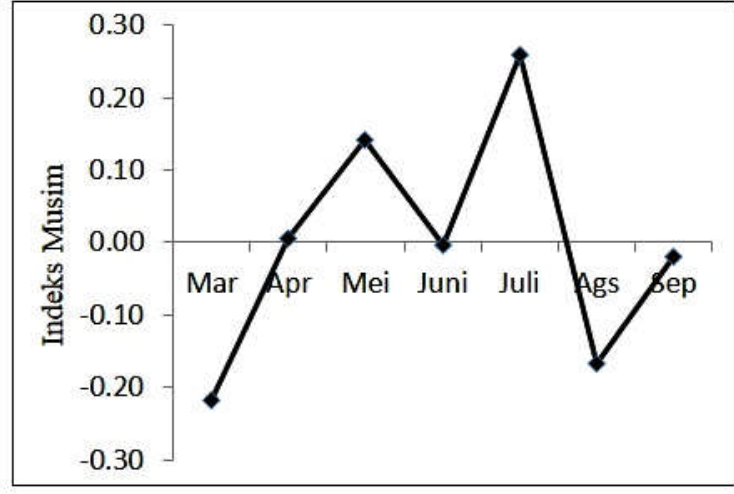

b

Gambar 6. a) Hasil tangkapan per unit upaya, dan b) Indeks musim penangkapan ikan tongkol komo (Euthynnus affinis) di Selat Malaka.

Figure 6. a)Catch per unit effort, and b) Index of fishing season of mackerel tuna (Eutyhynnus affinis) in Mallaca Strait.

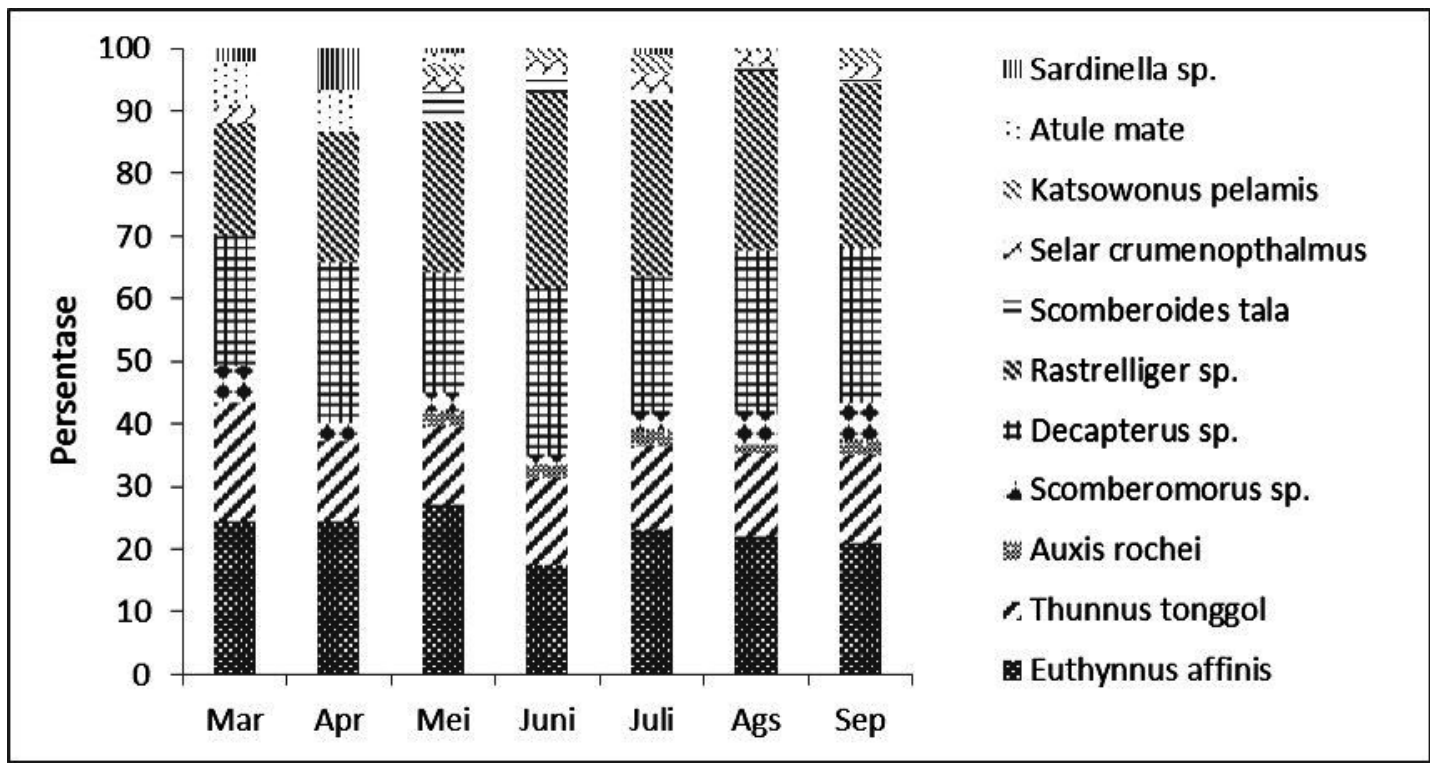

Gambar 7. Komposisi tangkapan pukat langgai secara bulanan di Selat Malaka.

Figure 7. Monthly catch composition of purse seine in Mallaca strait.

\section{Bahasan \\ Parameter Populasi}

Pada penelitian ini ikan tongkol komo di Selat Malaka mempunyai laju pertumbuhan ( $K=0,96 /$ tahun) dan kematian alami ( $M=1,38 /$ tahun) lebih tingggi, sebaliknya panjang maksimal ( $\mathrm{L}_{\infty}=64,25 \mathrm{cmFL}$ ) lebih rendah dibandingkan yang dijumpai di Tanzanaia masing-masing $\mathrm{K}=0,78 /$ tahun, $M=1,09 /$ tahun, $\mathrm{L}_{\infty}=89,25 \mathrm{cmFL}$ (Johnson \& Tamatamah, 2013) dan di Teluk Persia masing-masing $\mathrm{K}=0,51 /$ tahun $\mathrm{M}=1,07 /$ tahun, $\mathrm{L}_{\infty}=87,66 \mathrm{cmFL}$ (Motlagh, 2010). Hasil hasil penelitian tersebut menunjukkan kesesuaian dengan pernyataan Beverton \& Holt (1956) dalam Ghosh et al., (2009) bahwa laju pertumbuhan dengan laju kematian alami berbanding lurus, tetapi berbanding terbalik dengan panjang maksimum yang dapat tercapai. Fenomena yang berbeda ditunjukkan oleh tongkol komo di Samudera Hindia dengan nilai K= 0,63/tahun, $\mathrm{L}_{\infty}=63,53 \mathrm{cmFL}, \mathrm{M}=1,07 /$ tahun (Jatmiko et al., 2014) dan di Laut Jawa dengan nilai $\mathrm{K}=0,91 /$ tahun, $\mathrm{L}_{\infty}=59,63 \mathrm{cmFL}, \mathrm{M}=1,13$ /tahun (Chodrijah et al., 2013). Sesuai pernyataan Beverton \& Holt (1956) dalam Ghosh et al., (2009), seharusnya ikan tongkol komo di Samudera Hindia dan di Laut Jawa memiliki panjang maksimum lebih tinggi dari Selat Malaka, karena memiliki laju pertumbuhan dan kematian alami lebih rendah. Faktor lain yang mempengaruhi panjang maksium yang dapat tercapai adalah intensitas penangkapan. Laju kematian karena penangkapan ( $F=1,41 /$ tahun) ikan tongkol komo di Selat Malaka lebih rendah dibandingkan di perairan Samudera Hindia Barat Sumatera dengan nilai $F=5,02 /$ tahun (Sulistyaningsih et al., 2014), tetapi lebih tinggi 
dibandingkan di perairan Tanzania dengan nilai $F=0,69 /$ tahun (Johnson \& Tamatamah, 2013). Laju pertumbuhan dan panjang maksimal ikan tongkol komo yang dapat tercapai, berbeda antar lokasi disebabkan karena adanya variabilitas kondisi lingkungan, intensitas penangkapan dan sampling error (Motlagh et al., 2010), kelimpahan dan jenis mangsa (Al-Zibdah \& Odat, 2007). Laju kematian yang berbeda antar perairan disebabkan oleh target penangkapan alat tangkap, migrasi dan faktor ontogenik (Johnson \& Tamatamah, 2013). Pada penelitian ini rasio $\mathrm{Z} / \mathrm{K}=2,91$, menurut Ghosh et al. (2009) bila rasio melebihi 2 berarti pengaruh kematian terhadap ikan tongkol komo di Selat Malaka lebih dominan dari pada pertumbuhan, sehingga walaupun laju pertumbuhan tergolong tinggi, panjang maksimum yang dapat tercapai rendah.

Tingkat pengusahaan ikan tongkol komo $(E=0,5 /$ tahun) di Selat Malaka lebih rendah dibandingkan di perairan Teluk Persia dengan nilai $E=0,72 /$ tahun (Motlagh et al., 2009) dan Barat Sumatra dengan nilai $\mathrm{E}=0,78$ /tahun dan di Laut Jawa 0,57/tahun (Chodrijah et al., 2013). Nilai $E=0,5 /$ tahun mengindikasikan tingkat pengusahaan ikan tongkol komo di Selat Malaka dalam batas ambang keadaan optimum. Dalam pengelolaan keadaan ini belum aman, karena menurut Gulland (1971) dikutif oleh Johnson \& Tamatamah (2013) keadaan optimum apabila nilai $\mathrm{F}=\mathrm{M}$ dan menurut Motlagh et al.(2010), pengelolaan aman untuk ikan pelagis apabila nilai $\mathrm{F}=0,4$.

\section{Aspek Biologi}

Panjang pertama matang gonad ikan tongkol komo di Selat Malaka dengan nilai $\mathrm{Lm}=41 \mathrm{cmFL}$, lebih kecil dibandingkan di Laut Jawa 43,2 cmFL (Masuswo \& Widodo, 2016), di Teluk Persia dengan nilai $L m=52$ cmTL (Motlagh et al., 2013) dan di perairan Taiwan $\mathrm{Lm}=48 \mathrm{cmFL}$ (Chiou et al., 2004), lebih besar dari ikan tongkol komo di Selat Sunda $L m=40,7-40,8$ cmFL (Ardelia et al., 2016) dan di perairan India Lm=37,7 cmFL (Rohit et al., 2012). Panjang pertama tertangkap ikan tongkol komo di Selat Malaka dengan pukat langgai $\mathrm{Lc}=34,5 \mathrm{cmFL}$ lebih kecil dibandingkan di Laut Jawa Lc $=44,54 \mathrm{cmFL}$ (Masuswo \& Widodo, 2016) dan di Teluk Persia Lc $=46,88 \mathrm{cmFL}$ (Motlagh et al., 2013), lebih besar dibandingkan di Selat Sunda $\mathrm{Lc}=30,8 \mathrm{cmFL}$ (Ardelia et al., 2016) dan di perairan Pakistan Lc=32,83 cmFL (Ahmed et al., 2015). Perbedaan Lm dan Lc disebabkan oleh perbedaan daerah tangkapan, tekanan penangkapan, ketersediaan energi, waktu dan musim saat pengambilan contoh (Johnson \& Tamatamah, 2013). Ganga (2010) menemukan ukuran pertama matang gonad dipengaruhi oleh suhu, kompetisi makanan dan kelimpahan populasi. Nilai Lc dan Lm pada penelitian ini menggambarkan penangkapan ikan tongkol komo di Selat Malaka, tidak melestarikan sumber daya perikanan. Menurut Jamal et al. (2011) apabila ikan yang didaratkan mempunyai $\mathrm{Lc}<\mathrm{Lm}$, berarti belum melakukan regenerasi dan tidak berkonstribusi menambah populasi baru yang dapat melestarikan sumber daya karena adanya tekanan penangkapan.

Kisaran panjang cagak ikan tongkol komo hasil tangkapan pukat langgai (purse seine) di Selat Malaka 16-60 cmFL dan rerata $38 \mathrm{cmFL}$ lebih sempit dibandingkan hasil tangkapan di perairan India dengan kisaran 14-80 cmFL dan rerata 45,9 cmFL (Rohit et al., 2012). Hubungan panjang berat ikan tongkol komo pada penelitian ini menunjukkan pertumbuhan allometrik positif sama dengan yang didapatkan di perairan Tanzania (Johnson \& Tamatamah, 2013).

Pada saat penelitian ukuran ikan tongkol komo yang didaratkan dari Selat Malaka dalam keadaaan kecil, diakibatkan bukan karena tekanan penangkapan yang bersifat kronis melainkan karena mata jaring yang digunakan berukuran kecil. Sifat pertumbuhan allometrik positif dengan ukuran ikan masih kecil (belum matang gonad) ini berarti ikan komo gemuk disebabkan faktor ketersediaan pakan yang mendukung di perairan Selat Malaka.

Puncak kematangan gonad dan indeks gonad ikan komo di Selat Malaka terjadi pada Maret dan November berbeda dengan di Teluk Aqaba-Lebanon puncak indek gonad terjadi pada Desember (Al-Zibdah \& Odat, 2007) dan di perairan Gujarat-India dengan puncaknya pada September (Amitkumar, 2015). Perbedaan bulan terjadi puncak kematangan gonad ini sesuai dengan pernyataan Nissar et al. (2015) bahwa musim puncak kematangan gonad berbeda antar regional dan berhubungan dengan terjadi penghangatan suhu permukaan laut. Chang et al. (1972) yang dikutif oleh Chiou et al. (2004) mengatakan bahwa puncak matang gonad dan awal pemijahan ikan tongkol komo bertepatan dengan suhu permukaan perairan yang hangat. Terjadinya dua puncak dari kematangan dan indek gonad ikan tongkol komo di Selat Malaka berhubungan dengan pola kenaikan suhu Selat Malaka pada Maret setelah suhu rendah pada akhir musim barat dan pada November setelah mengalami penurunan suhu pada musim timur (Mubarak et al., 2016). Pola bimodal kematangan gonad ikan tongkol komo juga ditemukan di perairan Tanzania dengan puncak pada November dan Februari, terjadi bersamaan dengan kenaikan suhu permukaan laut (Johnson \& Tamatamah, 2013). 
Jenis isi lambung ikan tongkol komo di Selat Malaka terdiri atas ikan yang mempunyai habitat yang menyebar mulai dari pantai yaitu ikan teri (Stolephorus sp.), hingga ikan yang bersifat oseanik seperti tongkol lisong kecil (Auxis sp.) dan ikan terbang (Cypselurus sp.) menandakan bahwa ikan tongkol komo bersifat migratori dan konsumen tingkat tinggi. Pada penelitian ini, jenis yang dominan adalah ikan teri sebesar $26,27 \%$, berbeda dengan yang ditemukan oleh Noegroho et al. (2013) di Barat Sumatera yang dominan berupa ikan layang (Decapterus sp.). Dominasi ikan teri pada lambung ikan komo umum ditemukan pada berbagai area, seperti di perairan Taiwan (Chiou et al., 2004) dan di Laut Arab (Nissar et al., 2015). Dominasi jenis isi lambung ikan dapat bervariasi sesuai dengan musim dan ukuran (Ganga, 2010). Pada isi lambung ikan tongkol komo ditemukan juga potongan plastik ini menggambarkan sifat pemakan opurtunis dan perairan Selat Malaka sudah tercemar.

Nisbah kelamin ikan tongkol komo di Selat Malaka betina : jantan $=1: 1,15$. Komposisi jantan lebih besar, umum terjadi pada ikan komo yang berukuran besar seperti di perairan Taiwan (Chiou et al., 2004) dan di perairan India (Amitkumar, 2015). Nisbah kelamin bervariasi antara area (Nissar et al., 2015).

\section{Aspek Penangkapan}

Ukuran pukat langgai (purse seine) di Selat Malaka panjangnya lebih besar dan lebarnya lebih kecil dibandingkan di Samudera Hindia Barat Sumatera dengan panjang $600 \mathrm{~m}$ dan lebar $120 \mathrm{~m}$ (Sulistyaningsih et al., 2014) dan di Laut Andaman dengan panjang $1.000 \mathrm{~m}$ dan lebar $100 \mathrm{~m}$ (Sa-ngangam et al., 2013).

Lebih kecilnya lebar purse seine di Selat Malaka menyesuaikan dengan kedalaman perairan laut dangkal. Penggunaan alat rumpon (FAD) merupakan alat bantu umum dalam penangkapan ikan pelagis dengan purse seine. Adanya rumpon ini membantu efisiensi operasional penangakapan dan meningkatkan hasil tangkapan (Noranarttragoon et al., 2013).

Puncak CPUE dan musim penangkapan ikan tongkol komo di Selat Malaka berlangsung pada Maret dan Juli. Menurut Williams (1963) ada beberapa hal yang berhubungan dengan terjadinya puncak penangkapan ikan tongkol komo yaitu penghangatan suhu, kelimpahan makanan dan puncak kematangan gonad. Hubungan suhu dengan puncak musim dan CPUE, didukung oleh hasil penelitian Mubarak et al. (2016) yang menemukan pada musim peralihan I dan akhir musim timur sampai dengan Peralihan II perairan Selat Malaka lebih hangat dari musim lainnya. Hubungan puncak musim dan CPUE dengan kematangan gonad, didukung oleh hasil penelitian yang mendapatkan puncak IKG terjadi pada bulan yang sama dengan puncak musim. Faktor lingkungan dan pola migrasi menyebabkan musim penangkapan berbeda bulan antar wilayah. Di Laut Andaman musim penangkapan ikan tongkol komo berlangsung pada Januari-Mei (Dhammasak, 1998) dan di perairan Oman berlangsung Oktober-November (Al-Kiyumi et al., 2013). CPUE pukat langgai (purse seine) di Selat Malaka $165-1.000 \mathrm{~kg} /$ trip (6-7 hari) lebih kecil dibandingkan di Laut Andaman sebesar 170,36 kg/ hari (Sa-nga-ngam et al., 2013).

Kesamaan habitat dan sifat bergerombol terhadap agregator dari ikan pelagis dan sifat selektifas purse seine menyebabkan tangkapan ikan tongkol komo berinteraksi dengan ikan pelagis lainnya. Basir et al. (2015) menemukan ikan tongkol komo merupakan tuna neritik yang dominan di Selat Malaka. Menurut Dhammasak (1998) kontribusi ikan tongkol komo terhadap tangkapan purse seine sebesar 13,73-23,09 $\%$. Kontribusi ikan tongkol komo terhadap hasil tangkapan purse seine di Selat Malaka $(22,81 \%)$ lebih besar dari kontribusi ikan tongkol komo yang tertangkap purse seine di berbagai area penangkapan. Di Laut Andaman komposisi tuna neritik yang tertangkap dengan purse seine meliputi: tongkol abuabu (Thunnus tonggol) 9,33\%, tongkol komo (Euthynnus affinis) 7,33\%, tongkol krai (Auxis thazard) dan tongkol lisosng (Auxis rochei) 2,99\% (Sa-ngangam et al, 2013). Ikan kembung (Rastrelliger spp.) dan ikan layang (Decapterus spp.) merupakan ikan pelagis kecil utama yang berinteraksi dengan hasil tangkapan ikan tongkol komo masing-masing berkontribusi $25,34 \%$ dan 23,44\%. Tertangkapnya ikan pelagis kecil dalam tangkapan ikan tongkol komo secara bersama juga terjadi di Teluk Thailand dengan yang dominan ikan banyar (Rastrelliger kanagurta) dan ikan layang (Decapterus russelli) masing-masing berkontribusi $25,4 \%$ dan $23,6 \%$ (Noranarttragoon et al., 2013).

\section{KESIMPULAN}

Pada penelitian ini ada beberapa parameter yang bersifat negatif dan positif terhadap kelestarian populasi ikan tongkol komo. Parameter yang bersifat negatif seperti ukuran ikan dan hasil tangkapan per unit usaha nilainya kecil. Parameter yang bersifat positif antara lain: rasio antara nilai kematian alami dengan nilai laju pertumbuhan masih dalam kisaran normal dan nilai tingkat pengusahaan masih dalam kisaran optimum. Pola kematangan gonad dan indeks 
kematangan gonad ikan tongkol komo di Selat Malaka bersifat bimodal dengan puncak pada Maret dan November. Ikan tongkol komo yang tertangkap di Selat Malaka didominasi ukuran belum matang gonad. Isi lambung ikan tongkol komo di Selat Malaka didominasi oleh teri (Stolephorus sp.). Puncak CPUE dan musim penangkapan ikan tongkol komo di Selat Malaka terjadi pada Maret dan Juli. Hasil tangkapan ikan tongkol komo di Selat Malaka berinteraksi dengan ikan pelagis kecil terutama ikan kembung (Rastrelliger spp.) dan ikan layang (Decapterus spp.). Berdasarkan pada hasil penelitian ini, penangkapan ikan tongkol komo di Selat Malaka masih dalam keadaan normal, tetapi perlu pengawasan terhadap mata jaring dan alat tangkap yang digunakan serta kegiatan penangkapan pada musim pemijahan. Adanya interaksi dengan jenis ikan pelagis kecil dan dominasi ikan teri dalam isi lambung, sehingga dalam pengelolaan ikan tongkol komo harus dilakukan bersama dengan kedua komoditi tersebut.

\section{PERSANTUNAN}

Diucapkan terima kasih kepada para peneliti dan karyawan Balai Riset Perikanan Laut serta para pihak yang tidak dapat disebutkan satu persatu yang telah membantu tersusunnya karya tulis ilmiah ini. Data yang digunakan dalam penulisan karya tulis ilmiah ini dikumpulkan dengan menggunakan anggaran APBN kegiatan penelitian Balai Riset Perikanan Laut tahun 2014.

\section{DAFTAR PUSATAKA}

Ahmed, Q., Yousuf, F., Sarfraz, M., Alia, Q. M., Balkhourd, M., Safie, S. Z., \& Ashraff, M. A. (2015). Euthynnus affinis (little tuna): fishery, bionomics, seasonal elemental variations, health risk assessment and conservational management. Frontiers in Life Science. 8(1), 71-96.

Al-Kiyumi, F. R., Al-kharusi, L., Nishida, T., \& AlSiyabi, B. (2013). Standardization of kawakawa (Euthynnus affinis) catch rates of drift gillnet fisheries in Sultanate of Oman. IOTC-2013-WPNT0331 Rev_2.

Al-Zibdah, M., \& Odat, N. (2007). Fishery status, growth, reproduction biology \& feeding habit of two scombrid fish from the gulf of aqaba, Red Sea. Lebanese Science Journal, 8(2), 3-20.

Amitkumar, M. H. (2015). Some aspect of the biology of little tuna (Euthynnus affinis) landed at Veraval Coast, Gujarat. International Journal of Zoology and Reseacrh. 5(6), 17-24.
Ardelia, V., Vitner, Y., \& Boer, M. (2016). Biologi reproduksi ikan tongkol Euthynnus affinis di perairan Selat Sunda. Jurnal IImu dan Teknologi Tropis. 8(2), 689-700.

Basir, S., Sallehudin, J., Faizal, E. M., \& Mokthar, N. A. (2016). Malaysia national report to the scientific committee of the indian ocean tuna commission. IOTC-2016-SC19-NR16.

Carpenter, K. E, \& Niem, V. H. (2001). The living marine reources of the Western Central Pacific. Volume 6. Bony fishes part 4 (Labridae to Latimeriidae) Estuarine Crocodiles, Sea turtles, Sea snakes and Marine mammals. FAO Species Identification Guide for Fishery Purposes. Food and Agriculture Organization of the United Nations. Rome: 3511-4232

Chiang, W. C., Hsu, H. H., Fu, S.C., Chen, S. C., Sun, C. L., Chen, W. Y., Liu, D. C., \& Su, W. C. (2011). Reproductive biology of longtail tuna (Thunnus tonggo/) from coastal waters of Taiwan. IOTC-WPNT:1-30.

Chiou, W. D., Lei-Zong Cheng, L. Z., \& Chen, K. W. (2004). Reproduction and Food Habits of Kawakawa Euthynnus affinis in Taiwan . J. Fish. Soc. Taiwan 31(1), 23-38.

Chiou, W. D., \& Lee, L. K. (2004). Migration of kawakawa Euthynnus affinis in the waters near Taiwan. Fisheries Science, 70, 746-757

Chodrijah, U., Hidayat, T., Noegroho, T. (2013). Estimasi parameter populasi ikan tongkol komo (Euthynnus affinis) di Perairan Laut Jawa. Bawal. 5(3). $167-174$

Dhammasak, P. (1998). Review of tuna fishing in Thailand. 1998. IOTC Proceedings No. 1. 7th Expert Consultation on Indian Ocean Tunas, Victoria, Seychelles, 9-14 November, 1998.

Ganga, U. (2010). Investigations on the biology of Indian Mackerel Rastrelliger kanagurta (Cuvier) along the Central Kerala coast with special reference to maturation, feeding and lipid dynamics. Thesis. Doctor of Philosophy Faculty of Marine Sciences. Department of Marine Biology, Microbiology and Biochemestry School of Marine Sciences Cochin University of Science and Technology Kochi682016, India. 
Jagerroos, S. (2016). Assessment of Living Resources in the Straits of Malacca, Malaysia: Case Study. J Aquac Mar Biol, 4 (1): 00070. DOI: 10.15406/ jamb.2016.04.00070 (diunduh 8 Okto 2017). http:/ /medcraveonline.com/JAMB/JAMB-04-00070.pdf

Jamal, M., Sondita, M.F.A., Haluan, J., \& Wiryawan, B. (2011). Pemanfaatan data biologi ikan cakalang (Katsuwonus pelamis) dalam rangka pengelolaan perikanan bertanggung jawab di perairan Teluk Bone. Jurnal Natur Indonesia, 14(1), 107-113.

Jatmiko, I., Sulistyaningsih, R, K., Nugroho, D. (2014). Laju pertumbuhan, laju kematian dan ekploitasi ikan tongkol komo, Euthynnus affinis (Cantor, 1849), di perairan Samudera Hindia Barat Sumatera. Bawal. 6(2), 69-76.

Johnson, M. G., \& Tamatamah, A. R. (2013). Length frequency distribution, mortality rate and reproductive biology of kawakawa (Euthynnus affinis- Cantor, 1849) in the Coastal Waters of Tanzania. Pakistan Journal of Biological Sciences 16(21), 12701278.

KKP. (2015). Kelautan dan Perikanan dalam angka tahun 2015. Pusat Data, Statistik dan Informasi. 308 hal

Matsumoto, T., \& Miyabe, N. (2002). Preliminary report on the maturity and spawning of bigeye tuna (Thunnus obesus) in the Central Atlantic Ocean. Col. Vol. Sci. Pap. ICCAT, 54(1), 246-260.

Masuswo, R. \& Widodo, A.A. (2016). Karakteristik Biologi ikan tongkol komo (Euthhynnus affinis) yang tertangkap jaring insang hanyut di Laut Jawa. Bawal Vol.8 (1):57-63

Motlagh, T.S., Hashemi, S. A., \& Kochanian P. (2010). Population biology and assessment of Kawakawa (Euthynnus affinis) in Coastal Waters of the Persian Gulf and Sea of Oman (Hormozgan Province). Iranian Journal of Fisheries Sciences. 9(2), 315326

Mubarak, Nurhuda, A., \& Ghalib, M. (2016). Analisis suhu permukaan laut Selat Malaka. Prosiding Seminar Nasional "Pelestarian Lingkungan \& Mitigasi Bencana" Pekanbaru, 28 Mei 2016.

Nissar, K. K. S., Rashid, F., Phadke, G. G., \& Desai, A. Y. (2015). Reproductive biology of little tuna (Euthynnus affinis) in the Arabian sea. Eco. Env. \& Cons. 21 (4), 115-118.
Noegroho, T., Hidayat, T., \& Amri, K. (2013). Some biological aspects of frigate tuna (Auxis thazard), Bullet Tuna (Auxis rochei), and Kawakawa (Euthynnus affinis) in West Coasts Sumatera IFMA 572, Eastern Indian Ocean. IOTC-2013WPNT03-19.

Noranarttragoon, P., Sinanan, P., Boonjohn, N., Khemakorn, P., \& Yakupitiyage, A. (2013). The FAD fishery in the Gulf of Thailand: time for management measures. Aquat. Living Resour. 26, 8596.

Pauly, D. (1980). A selection of a simple methods for the assessment of the tropical fish stocks. FAO Fish. Circ. FIRM/C729. Roma. p.54.

Rohit, P., Chellappan, A., Abdussamad, E. M., Joshi, K. K., Saidkoya, K. P., Sivadas, M. , Ghosh, S., Rathinam, A. M. M., Kemparaju, S., Dhokia, H. K., Prakasan, D., \& Beni, N. (2012). Fishery and bionomics of the little tuna, Euthynnus affinis (Cantor, 1849) exploited from Indian waters. Indian J. Fish., 59(3), 33-42.

Sa-nga-ngam, C., Nootmorn, P., Jaiyen, T., Boonsuk, S., \& Loychuen, K. (2013). Catch and Size Distribution of Neritic Tunas from Purse seine in Andaman sea Coast of Thailand. IOTC-2013WPNT03-15.

Sulistyaningsih, R. K., Jatmiko, I., \& Wujdi, A. (2014). Length frequency distribution and population parameters of kawakawa (Euthynnus affinis-Cantor, 1849) caught by purse seine in the Indian Ocean (a Case Study in Northwest Sumatera IFMA 572). IOTC-2014-WPNT04-20.

Udupa, K. S. (1986). Statistical method of estimating the size at first maturity in fishes. Fishbyte, 4 (2), 8-10. ICLARM. Metro Manila.

Williams, F. (1963). Synopsis of biological data on little tuna euthynnus affinis (cantor) 1850 (Indian Oceans). Fisheries Division Branch Food and Agriculture Organization of the United Nations, Rome.

Zudaire, I., Murua, H., Grande, M., Korta, M., Arrizabalaga, H., Areso, J., \& Molina, A. D. (2010). Reproductive biology of yellowfin tuna (Thunnus albacares) in the Western and Central Indian Ocean. IOTC-WPTT:48. 